\title{
Enhancement of post harvest fruit quality and leaf curl disease tolerance in tomato through hybrid breeding
}

\author{
N. Pandiarana ${ }^{1}$, Shende Varun Durwas ${ }^{2}$, Tania Seth $^{2}$, Soumitra Chatterjee ${ }^{3}$, Subrata Dutta ${ }^{3}$ \\ and Arup Chattopadhyay ${ }^{*}$
}

${ }^{1}$ Department of Vegetable Crops, Faculty of Horticulture, Bidhan Chandra Krishi Viswavidyalaya, Mohanpur -741252, Nadia (West Bengal), INDIA

${ }^{2}$ Department of Genetics and Plant Breeding, Faculty of Agriculture, Bidhan Chandra Krishi Viswavidyalaya, Mohanpur-741252, Nadia (West Bengal), INDIA

${ }^{3}$ All India Coordinated Research Project on Vegetable Crops, Directorate of Research, Bidhan Chandra Krishi Viswavidyalaya, Kalyani-741235, Nadia (West Bengal), INDIA

*Corresponding author. E-mail: chattopadhyay.arup@gmail.com

Received: February 10, 2015; Revised received: June 15, 2015; Accepted: July 30, 2015

\begin{abstract}
Development of hybrids tolerant to leaf curl virus disease along with good post harvest/processing traits is the major thrust areas in tomato breeding now-a-days. A study was undertaken following $7 \times 7$ half diallel mating design utilizing four exotic and three indigenous lines to identify potential donors and crosses, to study the extent of heterobeltiosis and dominance behaviour, and to assess the genetic control of post harvest quality traits along with disease tolerance in tomato. Breeding strategies to improve characters governed by different types of gene action are discussed. Two parental lines, CLN 2777F and CLN 2777E could be utilized further in tomato breeding programme as they were identified as the most promising general combiners for fruit yield, processing quality and ToLCV tolerance. The maximum extent of heterobeltiosis $(104.17 \%)$ was found in pericarp thickness followed by fruit yield plant ${ }^{-1}(63.57 \%)$ and PDI of ToLCV disease $(-60.00 \%)$. The hybrids also exhibited various degrees of dominance effects. The study could also able to identify a promising cross 'CLN 2777E $\times$ CLN 2777F' which could be recommended for commercial exploitation after critical study in leaf curl disease prone areas of the tropics and sub-tropics.
\end{abstract}

Keywords: Combining ability, Heterobeltiosis, ToLCV tolerance, Tomato, Post harvest quality

\section{INTRODUCTION}

Tomato (Solanum lycopersicum), a crop of Peru-Ecuador origin, is widely being used as salad as well as a variety of processed products (Chattopadhyay et al., 2013) However, the quality of different value added products of tomato depends on phyico-chemical parameters like fruit weight, polar diameter, locules per fruit, TSS, sugar, titratable acidity, ascorbic acid, lycopene and $ß$-carotene contents of fruit which have been reported to vary greatly with variety/hybrid (Chattopadhyay et al., 2011; Sherpa et al., 2014). Resistance to biotic stresses apart from post harvest quality is one of the most prominent tomato breeding issues now-a-days. The major problem faced by the growers in the Gangetic plains of eastern India is the huge incidence of tomato leaf curl virus (ToLCV) particularly in early-autumn crop which is more remunerative than the main winter harvest (Chattopadhyay et al., 2011). The disease can cause yield loss up to $100 \%$ in favourable condition (Kalloo and Banerjee, 2000). Since the insect vector, whitefly (Bemisia tabaci) is difficult to control; breeding ToLCV resistant hybrid provides an attractive strategy to manage the disease in a better way. Some earlier studies showed that resistance to ToLCV/ TYLCV was either controlled by a few major genes (Banerjee and Kalloo, 1987) or polygenes (Hazra and Nath, 2008). Genetic studies have led to the mapping of five TYLCV resistance genes which are being exploited for resistance breeding ( $\mathrm{Ji}$ et al., 2007; Ji et al., 2009; Hutton et al., 2012). Though many loci (i.e. $T y-1$ to $T y-5)$ for TYLCV resistance have been described, the genes conferring stable resistance have not yet been identified.

Hybrid technology in tomato has emerged as one of the most potential technologies since 1908 and it will have to go a long way throughout the world in coming decade also to meet many challenges. Breeders usually prefer to develop $F_{1}$ hybrids, not only for yield, but also for their earliness, uniformity, keeping quality and protection against many biotic stresses. The ability of the hybrids to resist diseases will depend upon the degree of resistance found in parental line (s). Disease resistance in tomato is often inherited as a dominant condition (Rick et al., 1956) suggesting that the $F_{1}$ breeding technique provides a unique opportunity for 
achieving the maximum genetic improvement while in other breeding methods it would be more time consuming and difficult to achieve. The proper identification and selection of parents based on their combining ability are essential in any hybridization programme. The information regarding relative magnitude of genetic variance, combining ability estimates and different types of gene action are important considerations to formulate a breeding strategy for the genetic improvement of tomato. Although many genotypes in tomato have superior horticultural traits but they transmit poorly because of some genetic hindrances in diverse cross combinations (Singh et al., 2014). Thus crossing of number of diverse genotypes in all possible combinations (diallel fashion) would be a reliable approach for the identification of superior recombinant(s). Keeping in view the importance of the study and lack of research work done in one of the most potential zones in India, the objectives of this study were a) to determine the genetic control of post harvest quality traits, yield and severity of leaf curl virus disease to frame the breeding strategies for their genetic improvement b) to assess the magnitude of heterobeltiosis for post harvest quality traits, yield and leaf curl disease tolerance, and their dominance behaviour.

\section{MATERIALS AND METHODS}

Plant materials and field growing: Seven parents (CLN 2777A, CLN 2777F, CLN 2777E, CLN 2768A, tolerant to ToLCV disease collected from AVRDC, Taiwan; H-24, BCT-82P, BCT-110 from India) were selected based on their combining ability from our previous studies (Chattopadhyay et al., 2011; Shende et al., 2012; Sherpa et al., 2014). Twenty-five days old seedlings of seven parents were transplanted in crossing block during 2011 at warm sub-tropical humid climate $\left(23.5^{\circ} \mathrm{N}\right.$ latitude and $89^{\circ} \mathrm{E}$ longitude at a mean sea level of $9.75 \mathrm{~m}$ ) under All India Coordinated Research Project on Vegetable Crops, Bidhan Chandra Krishi Viswavidyalaya, Kalyani, Nadia, West Bengal, India. Seven parents were crossed in diallel fashion without reciprocals and hybrid seeds were extracted by fermentation method for the next year evaluation. Seedlings of 7 parental lines along with $21 \mathrm{~F}_{1}$ 's were transplanted in separate plots measuring $3.6 \mathrm{~m} \times 3.6 \mathrm{~m}$ at $60 \mathrm{~cm}$ in both ways in the main field following Randomized Block Design with three replications during $1^{\text {st }}$ week of September, 2012. The cultural practices scheduled for raising good crop was followed in time (Chattopadhyay et al., 2007).

Observations recorded: The observations were recorded on fruit weight $(\mathrm{g})$, polar diameter $(\mathrm{cm})$, equatorial diameter $(\mathrm{cm})$, locules fruit $^{-1}$, pericarp thickness $(\mathrm{mm})$ by digital vernier calipers; total soluble solids ( ${ }^{\circ}$ Brix) of fruit by digital hand refractometer; titratable acidity (\%) of fruit, vitamin C (mg/100 g) content of fruit and lycopene $(\mathrm{mg} / 100 \mathrm{~g})$ content of fruit as per the standard methods (Ranganna, 1986) from ten randomly selected fruits of each replication, and fruit yield plant ${ }^{-1}(\mathrm{~kg})$ both from the parents and $F_{1}$ hybrids taken from cumulative harvests of each plot. Tomato leaf curl virus (ToLCV) disease symptoms and disease severity were recorded from each plant of a genotype in each plot at 15-days intervals starting from 30 days after transplanting (DAP) up to 120 DAP. Reaction of the parents and hybrids to ToLCV disease was assessed based on percent disease incidence, percent disease index (PDI), symptom severity and coefficient of infection (CI) (Kalloo and Banerjee, 2000; Banerjee and Kalloo, 1987). Percent disease index (PDI) from the numerical ratings (0-4 scale) was calculated by the following formula.

$\mathrm{PDI}=\frac{\sum \text { Numerical ratings }}{} \times 100$

Highest grade of rating $\times$ total number of plants Examined

Statistical analysis: The criterion for judging the performance of parents and hybrids against ToLCV disease has been worked out by aggregating PDI values at different days after transplanting. The process is better known as computing a composite index. The procedure for computing a composite index had followed two steps:

Step I: Transformation of the original variable to a new one.

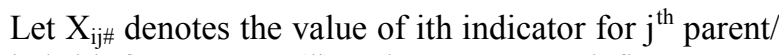
hybrid for tomato (\#). Then we can define a new variable $\mathrm{Y}_{\mathrm{ij} \#}$ such that

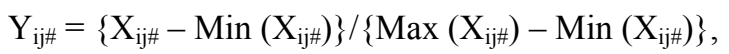
(1)

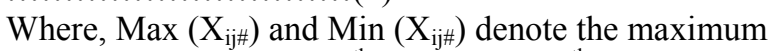
and minimum values of $\mathrm{i}^{\text {th }}$ indicator for $\mathrm{j}^{\text {th }}$ parent/ hybrid for tomato. Value of the newly transformed variable $\left(\mathrm{Y}_{\mathrm{ij} \#)}\right)$ varies from zero to one.

$\mathrm{Y}_{\mathrm{j} \#}=\sum_{\mathrm{i}=1}^{\mathrm{m}} \mathrm{w}_{\mathrm{i}} \mathrm{Y}_{\mathrm{ij}}$

where, $\mathrm{w}_{\mathrm{i}}\left(0<\mathrm{w}_{\mathrm{i}}<1\right.$ and $\left.\sum_{\mathrm{i}=1}^{\mathrm{m}} \mathrm{w}_{\mathrm{i}}=1\right)$ are arbitrary

weights. The calculation of weight is done as follows:

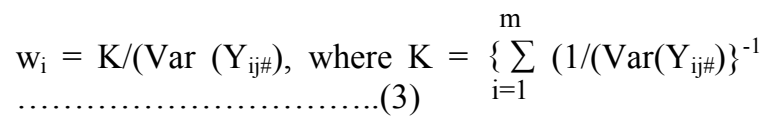

Estimation of heterosis over better-parent was calculated by the following formula

$$
\begin{aligned}
& \mathrm{H}_{2}(\%)=\frac{\overline{\mathrm{F}_{1}}-\overline{\mathrm{BP}}}{\overline{\mathrm{BP}}} \times 100 \\
& \text { S.E. }\left(\mathrm{H}_{2}\right)=\sqrt{2 \mathrm{Xve} / \mathrm{r} ;}, \text { 't'value }=\mathrm{H}_{2} / \text { S.E. }\left(\mathrm{H}_{2}\right)
\end{aligned}
$$

Calculated $\mathrm{t}$ was tested against table value of ' $\mathrm{t}$ ' at error degrees of freedom. 
Where $\mathrm{V}_{\mathrm{e}}=$ error mean square obtained from R.B.D. analysis, $\overline{\mathrm{F}}_{1}=$ mean of $\mathrm{F}_{1},=\overline{\mathrm{BP}}$ mean of the better parent, S.E. $=$ Standard error.

The dominance estimates (D.E.) were computed with the following formula (Smith, 1952).

D.E. $=\mathrm{F}_{1}-\mathrm{MP} / 0.5 \times \mathrm{P}_{2}-\mathrm{P}_{1}$,

Where, $\mathrm{F}_{1}=$ mean value of the hybrid population; $\mathrm{MP}=$ Mid-parent; $\mathrm{P}_{2}=$ Mean of the highest parent; $\mathrm{P}_{1}$ $=$ Mean of the lowest parent. Complete dominance was realized when D.E. $=+1$; while partial dominance is indicated when D.E. is between -1 and +1 ; D.E. = zero indicates absence of dominance. Over dominance was considered when D.E. exceeds \pm 1 . The ' + ' and '-' signs indicate the direction of dominance of either parent.

Combining ability variances and effects were worked out following Model 1 and Method 2 (Griffing, 1956). Method 2 is applicable to the present study as parents and one set of non-reciprocal $\mathrm{F}_{1}$ 's were included. Model 1 assumes that variety and block effects are constant but environmental effect is variable and the experimental material is the population about which inferences are to be made. Statistical analyses were done using SPSS Professional Statistics version 7.5 (SPSS Inc., Chicago, Ill.).

\section{RESULTS AND DISCUSSION}

Gene action of different characters: In tomato, much attention is to be paid to fixable type of gene effect for its improvement. The importance of non-additive gene effect may not be worthy as such. The analysis of variance indicated existence of wide genetic diversity among the genotypes tested since the effect of genotypes was significant $(\mathrm{p}<0.01)$ for all the traits under study (Table 1). The analysis of variance for combining ability showed that gca and sca mean squares were highly significant $(\mathrm{p}<0.01)$ for all the characters in $F_{1}$ generation (Table 2) indicating the importance of both additive and non-additive genetic control of these traits. The predictability ratio (Baker, 1978) could easily be judged the relative importance of additive and non-additive variances in the genetic control of various quantitative traits. The present study illustrated that the predictability ratios were less than 0.50 for most of the post harvest quality characters including yield and PDI of ToLCV disease indicating the preponderance of non-additive genetic control of these traits (Table 2). On the contrary, the predictability ratios were between greater than 0.50 and less than 0.80 in case of polar diameter, equatorial diameter and locules fruit ${ }^{-1}$ which are indicative of both additive and non-additive gene action. These findings suggested heterosis breeding as the best possible option for improving fruit weight, pericarp thickness; total soluble solids, acidity, vitamin C; lycopene percent disease index of ToLCV and fruit yield plant ${ }^{-1}$ which were governed by non-additive gene action. On the other hand, the use of diallel selective mating (Jensen, 1970) or mass selection with concurrent random mating (Redden and Jensen, 1974) or restricted recurrent selection by intermating the most desirable segregants followed by selection (Shende et al., 2012) might be some effective breeding strategies for the improvement of characters controlled by both additive and non-additive type of gene action. Not many findings were available on the genetic control of post harvest fruit quality traits and leaf curl disease severity in tomato. The importance of non-additive gene action for the conditioning of fruit weight (Shende et al., 2012), TSS (Chattopadhyay et al., 2011), fruit acidity (Chattopadhyay et al., 2011), vitamin C content of fruit (Kumar et al., 2013), lycopene content of fruit and percent disease index (PDI) of ToLCV disease (Dharmatti et al., 2004), and fruit yield plant ${ }^{-1}$ (Shende et al., 2012; Sherpa et al., 2014) have also earlier been reported. The equal importance of both additive and non-additive gene actions for the control of polar diameter of fruit (Hazra and Nath, 2008), equatorial diameter of fruit and locules fruit ${ }^{-1}$ (Mondal et al., 2009) have also been documented. On the contrary to the present findings, previous workers also noted the importance of non-additive genetic effects for locules fruit $^{-1}$ (Chattopadhyay et al., 2011; Sherpa et al., 2014), and additive gene effect for PDI of ToLCV disease (Farzane et al., 2012). The genetic constitution of the donor parents, environmental variation, crossing techniques used in analyzing the data and the precision of the experiment might play some important role for such disparities from previous results.

GCA and SCA effects: The gca effects varied greatly among the parents in respect of different quantitative traits. The highest significant and positive gca effects had shown by CLN 2777F for fruit yield plant ${ }^{-1}$ along with fruit weight, polar diameter, equatorial diameter, pericarp thickness, fruit acidity, vitamin $\mathrm{C}$ content and lycopene content of fruit followed by CLN 2777E for fruit weight, polar diameter, equatorial diameter, pericarp thickness, TSS, fruit acidity, lycopene and fruit yield plant $^{-1}$. Rest of the parents showed non-significant gca effects for fruit yield plant ${ }^{-1}$ (Table 3). Negatively significant gca effects for PDI of ToLCV disease were displayed by CLN 2777F and CLN 2777E. The highest per se performance for fruit yield plant $^{-1}$ along with fruit weight, polar diameter, equatorial diameter, pericarp thickness and TSS content of fruit was recorded in CLN 2777E followed by CLN 2777F. Significant and positive gca effects for fruit weight (Farzane et al., 2012) and fruit yield plant ${ }^{-}$ ${ }^{1}$ (Izge and Garba, 2012; Sherpa et al., 2014) have also been reported. Considering per se performance and gca effects, two parents namely, CLN $2777 \mathrm{~F}$ and CLN $2777 \mathrm{E}$ could be identified as good donor parents for improvement of fruit yield having better processing quality traits and tolerance to leaf curl virus in future breeding programme. Specific combining ability effects represent dominance and epistatic components of genetic variation which are not fixable but the crosses with high sca effects involving good general 
N. Pandiarana et al. / J. Appl. \& Nat. Sci. 7 (2) : 606 - 615 (2015)

609
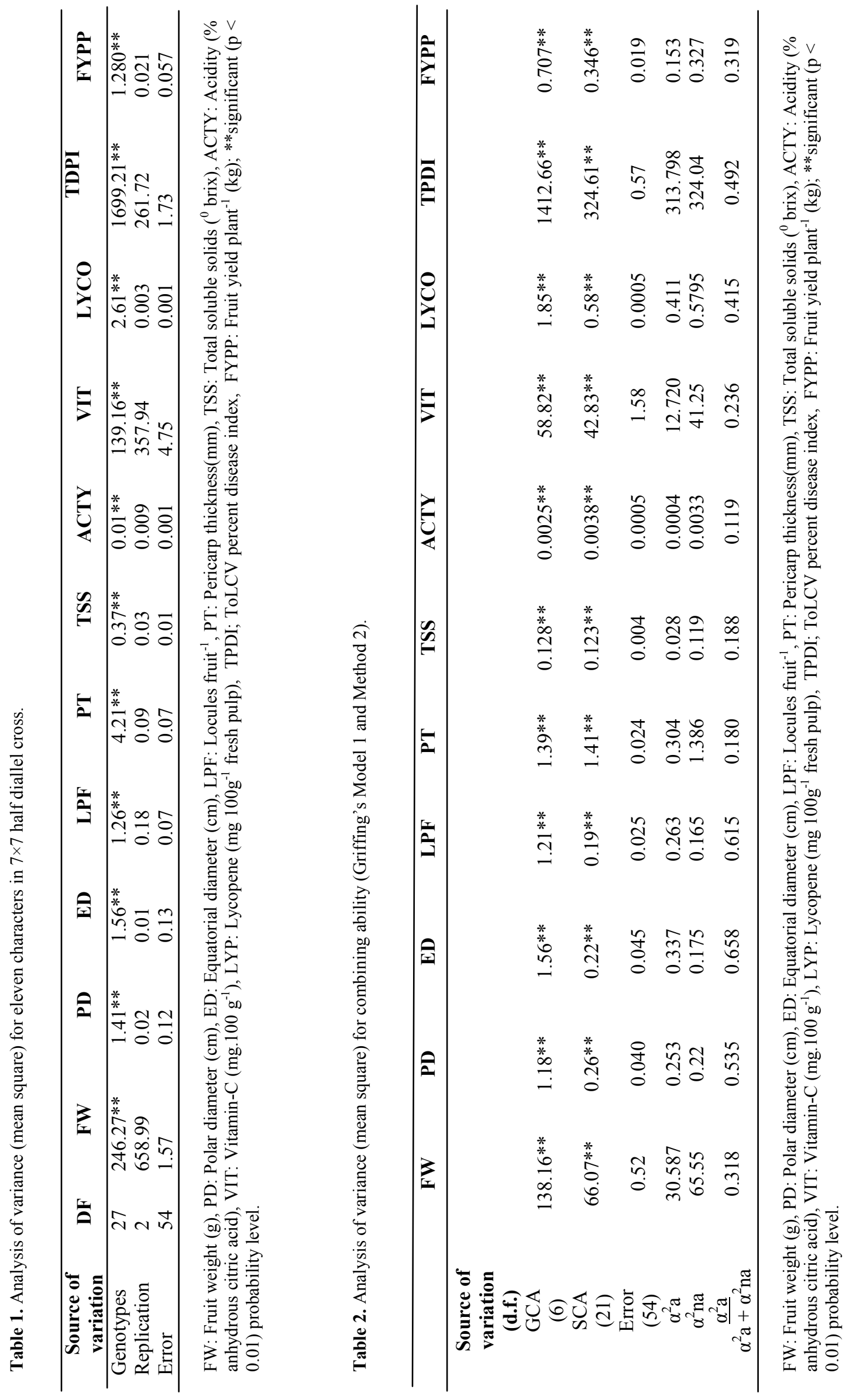
N. Pandiarana et al. / J. Appl. \& Nat. Sci. 7 (2) : 606 - 615 (2015)

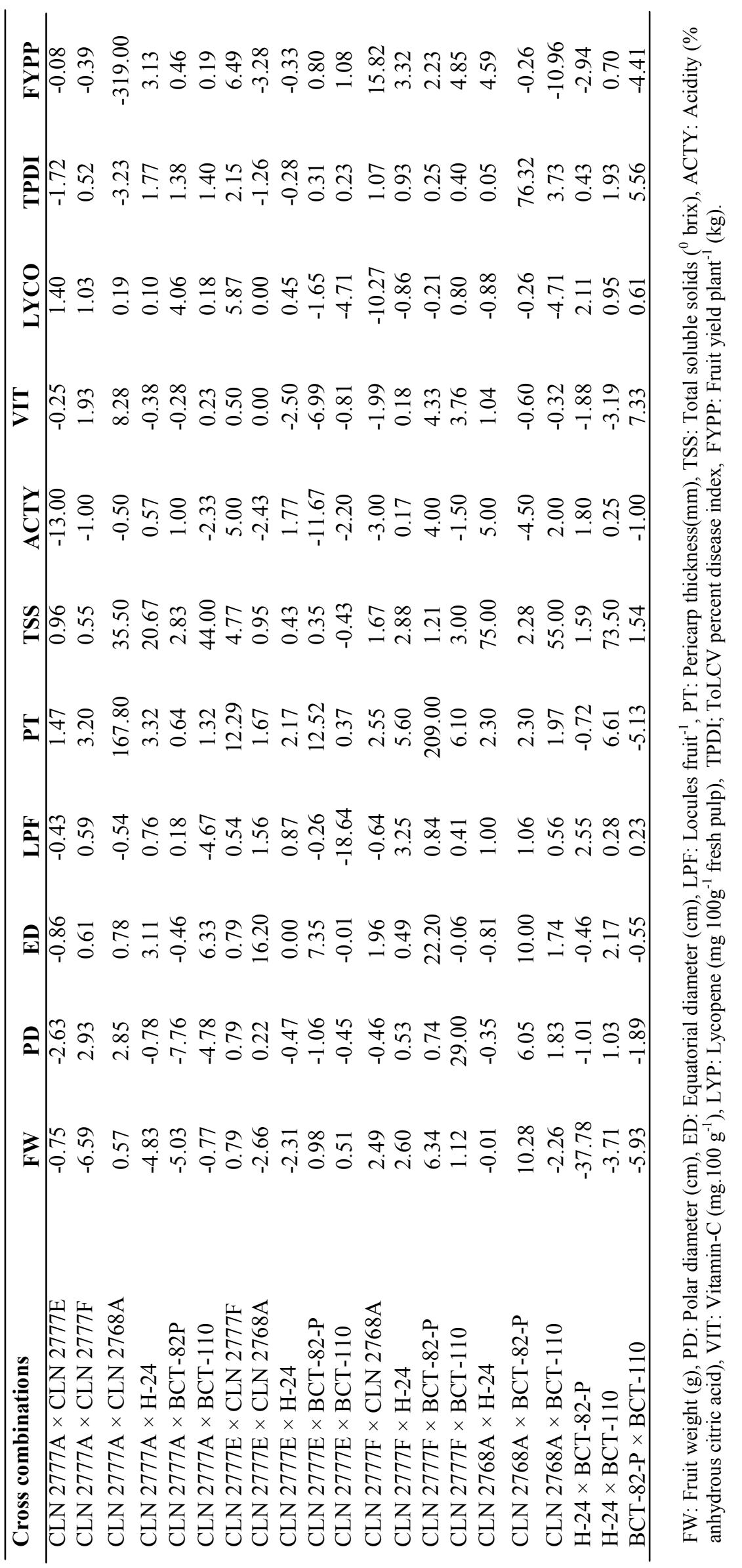


Table 5. Percent disease index (PDI) of ToLCV disease in 7 parents and 21 crosses at different growth stages.

\begin{tabular}{|c|c|c|c|c|c|c|c|c|}
\hline Parents/Crosses & 30DAT & 45DAT & 60DAT & 75DAT & 90DAT & 105DAT & 120DAT & $\begin{array}{l}\text { Composite } \\
\mathrm{Z} \text {-scoring } \\
\end{array}$ \\
\hline CLN 2777A & 3.57 & 10.20 & 16.71 & 25.00 & 30.36 & 39.29 & 42.86 & 0.49 \\
\hline CLN 2777E & 0.00 & 0.00 & 0.00 & 0.00 & 1.92 & 3.84 & 5.75 & 0.00 \\
\hline CLN 2777F & 0.00 & 0.00 & 1.56 & 3.12 & 5.21 & 6.42 & 8.28 & 0.04 \\
\hline CLN 2768A & 3.33 & 6.25 & 18.75 & 31.25 & 40.00 & 46.87 & 62.50 & 0.57 \\
\hline $\mathrm{H}-24$ & 10.41 & 22.91 & 35.41 & 43.75 & 54.16 & 62.50 & 81.25 & 1.00 \\
\hline BCT-82-P & 1.92 & 9.60 & 28.84 & 32.69 & 34.61 & 48.67 & 61.53 & 0.60 \\
\hline BCT-110 & 1.92 & 9.60 & 21.15 & 28.84 & 36.53 & 40.38 & 51.92 & 0.53 \\
\hline Mean & 3.02 & 8.36 & 17.48 & 23.52 & 28.97 & 35.42 & 44.87 & - \\
\hline $\mathrm{CLN} 2777 \mathrm{~A} \times \mathrm{CLN} 2777 \mathrm{E}$ & 6.25 & 9.37 & 21.87 & 25.00 & 31.25 & 40.62 & 56.25 & 0.57 \\
\hline CLN 2777A $\times$ CLN 2777F & 0.00 & 0.00 & 0.00 & 4.16 & 8.33 & 12.50 & 16.66 & 0.07 \\
\hline $\mathrm{CLN} 2777 \mathrm{~A} \times \mathrm{CLN} 2768 \mathrm{~A}$ & 6.25 & 12.50 & 25.00 & 28.12 & 31.25 & 59.37 & 84.37 & 0.70 \\
\hline CLN 2777A $\times$ H-24 & 1.56 & 9.37 & 10.93 & 15.62 & 17.86 & 20.31 & 28.12 & 0.31 \\
\hline CLN 2777A $\times$ BCT-82P & 1.79 & 10.71 & 17.86 & 21.43 & 26.79 & 35.71 & 39.29 & 0.44 \\
\hline CLN 2777A $\times$ BCT-110 & 0.00 & 5.36 & 14.29 & 17.86 & 25.00 & 33.93 & 41.07 & 0.35 \\
\hline CLN 2777E $\times$ CLN $2777 \mathrm{~F}$ & 0.00 & 0.00 & 0.00 & 0.00 & 1.56 & 3.12 & 4.29 & 0.00 \\
\hline $\mathrm{CLN} 2777 \mathrm{E} \times \mathrm{CLN} 2768 \mathrm{~A}$ & 10.00 & 20.00 & 35.00 & 35.00 & 45.00 & 50.00 & 70.00 & 0.86 \\
\hline CLN 2777E $\times$ H-24 & 0.00 & 8.33 & 20.83 & 29.16 & 33.33 & 41.66 & 54.16 & 0.49 \\
\hline CLN 2777E $\times$ BCT-82-P & 0.00 & 6.25 & 12.50 & 15.62 & 18.75 & 21.87 & 25.00 & 0.27 \\
\hline CLN 2777E $\times$ BCT-110 & 3.12 & 7.81 & 9.37 & 10.93 & 15.62 & 17.18 & 23.43 & 0.27 \\
\hline CLN 2777F $\times$ CLN 2768A & 0.00 & 0.00 & 0.00 & 1.56 & 3.12 & 5.21 & 6.42 & 0.02 \\
\hline CLN $2777 \mathrm{~F} \times \mathrm{H}-24$ & 0.00 & 1.56 & 3.12 & 6.25 & 6.25 & 7.81 & 10.93 & 0.08 \\
\hline CLN 2777F $\times$ BCT-82-P & 0.00 & 1.56 & 6.25 & 9.37 & 14.06 & 20.31 & 28.12 & 0.18 \\
\hline CLN 2777F $\times$ BCT-110 & 0.00 & 3.57 & 7.25 & 10.71 & 14.28 & 17.85 & 21.42 & 0.19 \\
\hline CLN 2768A $\times$ H-24 & 0.00 & 1.56 & 3.57 & 5.36 & 10.71 & 39.28 & 71.42 & 0.25 \\
\hline CLN 2768A $\times$ BCT-82-P & 0.00 & 0.00 & 3.57 & 7.14 & 14.28 & 17.85 & 25.00 & 0.14 \\
\hline CLN 2768A $\times$ BCT -110 & 3.57 & 5.36 & 8.93 & 17.86 & 28.57 & 33.93 & 37.50 & 0.38 \\
\hline H-24 × BCT-82-P & 1.56 & 7.81 & 20.31 & 31.25 & 35.93 & 53.12 & 67.18 & 0.57 \\
\hline $\mathrm{H}-24 \times \mathrm{BCT}-110$ & 3.33 & 8.33 & 10.00 & 13.33 & 20.00 & 26.66 & 38.33 & 0.35 \\
\hline BCT-82-P $\times$ BCT-110 & 1.66 & 7.81 & 15.00 & 18.33 & 18.33 & 23.33 & 30.00 & 0.33 \\
\hline Mean & 1.86 & 5.98 & 11.52 & 15.17 & 20.01 & 27.69 & 37.09 & - \\
\hline
\end{tabular}

combiner parents can be exploited in future breeding programme (Hannan et al., 2007). Normally sca effects do not contribute much for the improvement of self-pollinated crop like tomato. However, crosses having desirable sca effects along with either two good combiner parents or any one of them could be effectively utilized in future breeding programme. The top three cross combinations viz., CLN 2777E $\times$ CLN 2777F, CLN 2777F $\times$ H-24 and CLN2777F $\times$ CLN2768A exhibited highly significant sca effects in desired direction for fruit yield plant ${ }^{-1}$ along with several post harvest quality traits and PDI of ToLCV disease and they are also having at least one parent as good general combiner, indicating that these hybrids 
would be expected to produce segregants of fixable nature in segregating generations through simple pedigree method (Shende et al., 2012).

The present study revealed different cross combinations namely, $\mathrm{H} \times \mathrm{H}, \mathrm{H} \times \mathrm{L} / \mathrm{L} \times \mathrm{H}$ and $\mathrm{L} \times \mathrm{L}$, where $\mathrm{H}$ stands for positive significant gca effect and $\mathrm{L}$ for negative gca effect of the parents (Table 3 ). Additive as well as additive $\times$ additive type of epistasis were involved in the $\mathrm{H} \times \mathrm{H}$ type cross combinations for fruit yield plant $^{-1}$, PDI of ToLCV disease, locules fruit ${ }^{-1}$, equatorial diameter, TSS and ascorbic acid contents of fruit. Desirable segregants could be isolated in early advance generation from this cross. In $\mathrm{H} \times \mathrm{L} / \mathrm{L} \times \mathrm{H}$ type of cross combinations for fruit weight, polar diameter, pericarp thickness, TSS, acidity of fruit, lycopene content, PDI of ToLCV and fruit yield plant 1 , predominantly additive effect was present in good combiners and possibly complementary epistatic effect in poor combiner and these two gene actions acted in complementary fashion to maximize the expression (Salimath and Bahl, 1985). In the cross involving L $\times$ L category, significant sca effects for fruit yield per plant and other fruit quality traits seemed to be played a very important role and high performance was due to non-additive gene action.

Estimation of heterobeltiosis: The estimates of heterobeltiosis reflected significant effects in desirable directions for almost all the characters studied, four hybrids for fruit weight, seven hybrids for polar diameter, nine hybrids for equatorial diameter, three hybrids for locules fruit ${ }^{-1}$, seventeen for pericarp thickness, fifteen hybrids for TSS content of fruit, six hybrids for titratable acidity, five hybrids for vitamin $\mathrm{C}$, six hybrids for lycopene content, nine hybrids for PDI of ToLCV disease and eight hybrids for fruit yield plant ${ }^{-1}$. The extent of heterobeltiosis in the present study is well comparable with the previous studies and varied from $-33.83 \%$ to $16.53 \%$ for fruit weight (Kumar et al., 2013), $-30.00 \%$ to $9.20 \%$ for polar diameter (Shende et al., 2012), $-21.54 \%$ to $11.92 \%$ for equatorial diameter (Shende et al., 2012), $48.23 \%$ to -19.70 locules fruit $^{-1}$ (Dharmatti et al., 2004), $-15.38 \%$ to $104.17 \%$ for pericarp thickness (Dharmatti et al., 2004), $-7.81 \%$ to $37.76 \%$ for TSS content (Mondal et al., 2009), $-41.30 \%$ to $30.76 \%$ for fruit acidity content (Kumar et al., 2006), -62.91\% to $35.93 \%$ for vitamin C content (Singh et al., 2005), $-56.10 \%$ to $31.56 \%$ for lycopene content, $1117.39 \%$ to $-60.00 \%$ for PDI of ToLCV disease (Sajjan, 2001), and -47.94 $\%$ to $63.57 \%$ for fruit yield plant $^{-1}$ (Sekhar et al., 2010). The highest significantly positive heterobeltiosis for fruit yield plant ${ }^{-1}$ was recorded in CLN $2777 \mathrm{~F}$ $\times$ CLN 2768A (63.57\%) followed by CLN 2768A $\times \mathrm{H}$ -24 (45.44\%), CLN 2777E × CLN 2777F (41.49\%), CLN 2777F $\times$ H-24 (36.78\%) and CLN 2777A $\times \mathrm{H}$ $-24(26.97 \%)$ along with other economic characters (Table 3). While the maximum negative heterobeltiosis for PDI of leaf curl disease severity was shown by CLN 2768A $\times$ BCT 82P (-60.00\%) followed by BCT
$82 \mathrm{P} \times \mathrm{BCT}-110(-42.21 \%)$ and CLN 2777E $\times \mathrm{CLN}$ $2777 \mathrm{~F}(-25.39 \%)$. On the basis of per se performance, the best hybrid for fruit yield plant ${ }^{-1}$ was CLN 2777E $\times$ CLN 2777F (3.925 $\mathrm{kg}^{-1}$ plant) and the top parent was CLN 2777E (2.774 $\mathrm{kg}^{-1}$ plant). Therefore, the cross CLN 2777E $\times$ CLN 2777F could be exploited commercially in ToLCV disease prone areas after necessary multilocational trials. On the other hand, the cross CLN 2768A $\times \mathrm{H}-24$ could be exploited for processing purpose considering high TSS (4.58 ${ }^{\circ}$ brix) and acidity $(0.51 \%)$ contents of fruit as suggested by Adsule et al. (1980).

Dominance effects of characters: The values of dominance estimates (Potence ratio) expressed in $21 \mathrm{~F}_{1}$ crosses are presented in table 4 . The potence ratio for fruit weight ranged from -37.78 to 10.28 , and they were more than +1 for fourteen crosses and between \pm 1 in seven crosses indicating over-dominance and partial dominance, respectively towards the higher fruit weight. Potence ratio of polar diameter varied from -7.76 to 29.00 , and there were more than +1 in twelve crosses, indicating over-dominance reaction along with the nine crosses which showed partial dominance effect for inheritance of this trait. In case of equatorial diameter, nine crosses exhibited over-dominance and eleven hybrids found to show partial dominance, whereas there was absence of dominance $(0.0)$ in one cross. However, locules fruit ${ }^{-1}$ expressed over-dominance in six crosses and partial dominance (between +1 ) in fourteen hybrids except one cross which showed complete dominance $(+1.0)$. In respect to pericarp thickness, eighteen crosses exhibited over-dominance except three crosses which exhibited partial dominance. TSS content of fruit expressed over dominance in fifteen crosses, partial dominance in six crosses in the inheritance of this trait. Regarding the acidity of the fruit, there were more than +1 in fourteen crosses indicating over-dominance and between \pm 1 in four hybrids indicating partial dominance and $(+1)$ in three crosses showing complete dominance towards the higher acidity of fruit. In case of vitamin $\mathrm{C}$ content eleven hybrids expressed over dominance and nine crosses expressed partial dominance and in one cross the absence of dominance $(0.00)$ was found. In case of lycopene content of fruit, nine crosses exhibited over dominance and eleven hybrids expressed partial dominance and a single cross showed absence of dominance. In case of PDI of leaf curl virus, twelve crosses expressed over dominance and nine hybrids exhibited partial dominance. Potence ratios for fruit yield plant $^{-1}$ ranged most widely from -319.00 to 15.82 , and there were more than +1 in thirteen crosses which exhibited over-dominance and between \pm 1 in eight crosses indicating partial dominance in the inheritance of this character. The results illustrated various degrees of dominance effects which corroborate the observations of previous workers (Jensen, 1970; Solieman et al., 2013) who found preponderance of non-additive genetic control for most of the studied 
traits, suggesting heterosis breeding for their improvement.

Disease severity of parents and hybrids: Information regarding evaluation of parents/hybrids for disease reaction by disease index as well as their composite $\mathrm{Z}$-scoring is lacking in tomato. Reactions of different parents and their corresponding hybrids, in terms of PDI values of ToLCV differed at different days after transplanting (DAT). All parents and hybrids showed comparatively lower PDI values from 30 to 45 DAT and the average PDI values at different growth stages varied from $3.02 \%$ to $44.87 \%$ in parents and from $1.86 \%$ to $37.09 \%$ in hybrids (Table 5). No disease severity was observed in CLN 2777 E up to 75 DAT and in CLN $2777 \mathrm{~F}$ up to 45 DAT. The PDI values among parents were consistently lower in CLN $2777 \mathrm{E}$ and CLN $2777 \mathrm{~F}$ and comparatively higher in $\mathrm{H}-24$ and CLN 2768A up to 120 DAT. Composite performance scoring of parents at different DAT also illustrated that CLN $2777 \mathrm{E}$ and CLN $2777 \mathrm{~F}$ had the minimum values. Similarly, no disease symptom was noticed in a cross involving two parents, CLN $2777 \mathrm{E}$ and CLN $2777 \mathrm{~F}$ up to 75 DAT and consistently lower in magnitude up to 120 DAT. The PDI values were also lower in magnitude in three other crosses, CLN $2777 \mathrm{~F} \times \mathrm{CLN}$ 2768 A, CLN $2777 \mathrm{~F} \times \mathrm{H}-24, \mathrm{CLN} 2777$ A $\times \mathrm{CLN}$ $2777 \mathrm{~F}$ up to $120 \mathrm{DAT}$. The composite performance scoring of these crosses also had lower values indicating low severity of ToLCV disease. Considering the PDI values and composite performance scoring of hybrids, the cross, CLN $2777 \mathrm{E} \times \mathrm{CLN} 2777 \mathrm{~F}$ had the lowest PDI value $(4.29 \%)$ and minimum $Z$-score $(0.00)$ followed by CLN $2777 \mathrm{~F} \times$ CLN 2768 A designated as the most field tolerant hybrids; CLN $2777 \mathrm{~F} \times \mathrm{H}-24$ and CLN $2777 \mathrm{~A} \times \mathrm{CLN} 2777 \mathrm{~F}$ could be categorized as moderately tolerant and the rest crosses were moderate to highly susceptible.

\section{Conclusion}

The breeding procedures applicable to improvement of studied characters governed by different types of gene action showed that improvement in post harvest quality traits coupled with leaf curl disease tolerance in tomato could be possible through heterosis breeding. Two exotic lines CLN 2777F and CLN 2777E could be identified as potential donors in future tomato breeding programme. Pericarp thickness of tomato exhibited the maximum heterobeltiosis (104.17\%) followed by fruit yield per plant $(63.57 \%)$ and PDI of ToLCV disease $(-60.00 \%)$. Direct commercial exploitation of the cross CLN $2777 \mathrm{E} \times$ CLN $2777 \mathrm{~F}$ owing to high per se $\left(3.925 \mathrm{~kg}\right.$ plant $\left.^{-1}\right)$ and heterobeltiosis $(41.49 \%)$ for fruit yield plant ${ }^{-1}$ as well as very low ToLCV disease severity $(4.29 \%$ at 120 DAP) may be recommended in the tropics and sub-tropics after its critical evaluation.

\section{ACKNOWLEDGEMENTS}

Authors wish to acknowledge Dr. B. Singh, Director,
IIVR, Varanasi, India and Dr. Ivi Chakraborty, Head, Department of Post Harvest Technology of Horticultural Crops, BCKV, Mohanpur, Nadia, West Bengal, India for providing necessary financial help and laboratory facility to conduct this study.

\section{REFERENCES}

Adsule, P.G., Dan, A. and Tikko, S.K. (1980). Studies on the evaluation of tomato cultivars for making juice. Indian Food Packer, 34: 18-20.

Baker, R.J. (1978). Issues in diallel analysis. Crop Science, 18:533-536.

Banerjee, M.K. and Kalloo, G. (1987). Sources and inheritance of resistance to leaf curl virus in Lycopersicon. Theoretical and Applied Genetics, 73: 707-710.

Chattopadhyay, Arup, Chakraborty, Ivi and Siddique, Wasim (2013). Characterization of determinate tomato hybrids: Search for better processing qualities. Journal of Food Processing and Technology, 4: 222. doi:10.4172/2157 -7110.1000222 .

Chattopadhyay, Arup, Dutta, Subrata, Dutta, Priyanka and Hazra, Pranab (2011). Studies on heterobeltiosis, combining ability and gene action in tomato (Solanum lycopersicum). International Journal of Plant Breeding, 5 (2): 88-93.

Chattopadhyay, A., Dutta, S., Bhattacharya, I., Karmakar, K. And Hazra, P. (2007). Technology for Vegetable Crop Production. Published by All Indian Coordinated Research Project on Vegetable Crops, Directorate of Research, Bidhan Chandra Krishi Viswavidyalaya, Kalyani: 741235, Nadia, West Bengal India, P.226.

Dharmatti, P.R, Patil, R.V. and Bhagvanthgoudar, M.H. (2004). Development of ToLCV resistant hybrids in tomato. Karnataka Journal of Agricultural Sciences, 17 (4): 769-774.

Farzane, A., Nemati, H., Arouiee, H., Kakhki, A.M. and Vahdati, N. (2012). The estimate of combining ability and heterosis for yield and yield components in tomato (Lycopersicon esculentum Mill.). Journal of Biology and Environmental Science, 6 (17): 129-134.

Griffing, B. (1956). Concept of general and specific combining ability in relation to diallel crossing system. Australian Journal of Biological Sciences, 90: 463-492.

Hannan, M.M., Ahmed, M.B., Razvy, M.A., Karim, R., Khatun, M., Haydar, A., Hossain, M. and Roy, U.K. (2007). Heterosis and correlation of yield and yield components in tomato (Lycopersicon esulentum Mill.). American Eurasian Journal of Scientific Research, 2 (2): 146-150.

Hazra, P. and Nath, S. (2008). Source of resistance in tomato and inheritance of host resistance for tomato leaf curl virus disease. Indian Journal of Agricultural Sciences, 78: 690-694.

Hutton, S.F., Scott, J.W. and Schuster, D.J. (2012). Recessive resistance to tomato yellow leaf curl virus from the tomato cultivar Tyking is located in the same region as Ty-5 on Chromosome 4. Hortscience, 47: 324-327.

Izge, A.U. and Garba, Y.M. (2012). Combining ability for fruit worm resistance in some commercially grown tomatoes in Lake Alau near Maiduguri and Hong in Adamawa state, Nigeria. Journal of Environmental Issues and Agriculture in Developing Countries, 4 (1): $38-44$.

Jensen, N.F. (1970) A diallel selective mating system for 
cereal breeding. Crop Science, 10: 629-635.

Ji, Y., Schuster, D.J and Scott, J.W. (2007). Ty-3, a begomovirus resistance locus near the tomato yellow leaf curl virus resistance locus $T y-1$ on chromosome 6 of tomato. Molecular Breeding, 20: 271-284.

Ji, Y., Scott, J.W., Schuster, D.J. and Maxwell, D.P. (2009). Molecular mapping of $T y-4$, a new tomato yellow leaf curl virus resistance locus on chromosome 3 of Tomato. Journal of the American Society for Horticultural Science, 134: 281-288.

Kalloo, G. and Banerjee, M.K. (2000). H-24: Moderately leaf curl resistant variety of tomato (Lycopersicon esculentum Mill.). Vegetable Science, 27: 117-120.

Kumar, R., Mishra, N.K., Singh, J., Rai, G., Verma, A. and Rai, M. (2006). Studies on yield and quality traits in tomato (Solanum lycopersicum (Mill.) Wettsd.). Vegetable Science, 33 (2):126-132.

Kumar, R., Srivastava, K., Singh, N.P., Vasistha, N.K., Singh, R.K and Singh, M.K. (2013). Combining ability analysis for yield and quality traits in tomato (Solanum lycopersicum L.). Journal of Agricultural Science, 5 (2): 213-218.

Mondal, C., Sarkar, S. and Hazra, P. (2009). Line x Tester analysis of combining ability in tomato ( $L$. esculentum Mill.). Journal of Crop and Weed, 5 (1): 53-57.

Ranganna, S. (1986). Manual Analysis of Fruits and Vegetable Products. Tata McGraw-Hill Publishing Company Ltd, New Delhi.

Redden, R.J. and Jensen, N.F. (1974) Mass selection and mating system in cereals. Crop Science, 14: 345-350.

Rick, C.M., Baughn, C.G. and Hall, B.J. (1956). Three new hybrid tomatoes. California Agriculture, 10: 4-5.

Sajjan, M.N. (2001). Heterosis, combining ability, RAPD analysis and resistance breeding for leaf curl virus and wilt in tomato (Lycopersicon esculentum Mill.). M.Sc.
(Agri.) Thesis submitted to University of Agricultural Sciences, Dharward, India.

Salimath, P.M. and Bahl, P.N. (1985) Heterosis and combining ability for earliness in chickpea (Cicer arietinum L). Indian Journal of Genetics and Plant Breeding, 45: 97-100.

Sekhar, L., Prakash, B.G., Salimath, P.M., Channayya, Hiremath, P., Sridevi, O. and Patil, A.A. (2010). Implications of heterosis and combining ability among productive single cross hybrids in tomato. Electronic Journal of Plant Breeding, 1 (4): 706-711.

Shende, V.D., Seth, T., Mukherjee, S. and Chattopadhyay, A. (2012). Breeding tomato (Solanum lycopersicum L.) for higher productivity and better processing qualities. SABRAO Journal of Breeding and Genetics, 44 (2): 302-321.

Sherpa, Pemba, Seth, Tania, Shende, Varun Durwas, Padiarana,N,Mukherjee,Subhra and Chattopadhya , Arup (2014). Heterosis, dominance estimates and genetic control of yield and post harvest quality traits of tomato. Journal of Applied and Natural Science, 6 (2): 625 - 632.

Singh, A. Gautam, J.P.S., Upadhyay, M. and Joshi, A. (2005). Heterosis for yield and quality characters in tomato. Crop Science, 29 (2): 285-287.

Singh, R. K., Rai, N., Singh, Major, Singh, S. N. and Srivastava, K. (2014). Genetic analysis to identify good combiners for ToLCV resistance and yield components in tomato using interspecific hybridization. Journal of Genetics, 93: 623-629.

Smith, H.H. (1952) Fixing transgressive vigour in Nicotiana rustica. In: Heterosis. Iowa State College Press, Ames, IA, USA.

Solieman, T.H., El-Gabry, M.A.H., Abido, A.I. (2013) Heterosis, potence ratio and correlation of some important characters in tomato (Solanum lycopersicum L.). Scientia Horticulturae, 150: 25-30. 